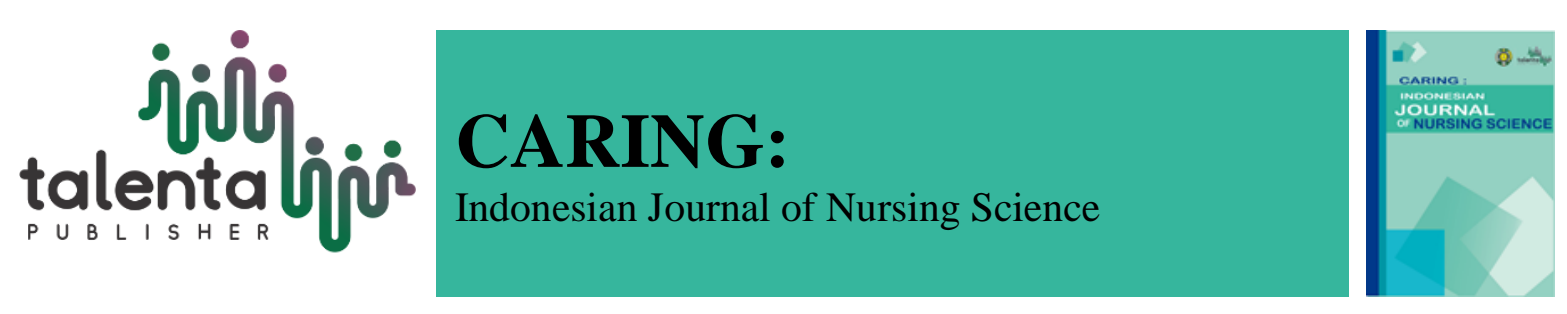

\title{
The Relationship Between Knowledge and Working Mother for Breastfeeding in Sidomulyo, Stabat
}

\author{
Rahmi Fitri, Nurhikmah Panjaitan \\ STIKES Putra Abadi Langkat - Stabat, Indonesia
}

\begin{abstract}
Breast milk contains substance known as IgA for the defense system in digestive tract against infection. This study aims to determine the relationship between knowledge and working mothers with exclusive breastfeeding in Sidomulyo, Stabat. The type of research used is a descriptive analytic survey using a cross sectional study. The sampling technique used accidental sampling with 150 as population and 30 people is involved as the research sample. The data analysis applied chi square test to determine the relationship between two variables. The results of this study revealed that there is a relationship between mother's knowledge of exclusive breast feeding with a significant level $(a)=5 \%(0.05)$ and $\mathrm{df}=2$, the result is value $=0.026$ at $\mathrm{df}=2$ where $\mathrm{sig}<\mathrm{a}(0.026<0.05)$ then Ho is rejected and $\mathrm{Ha}$ is accepted. Therefore, mothers are advised to continue to provide exclusive breastfeeding to their babies even though they work by storing breast milk in the refrigerator.
\end{abstract}

Keywords: knowledge, work of mothers, exclusive breast feeding

Received 10 November 2020 | Revised 13 December 2020 | Accepted 30 December 2020

\section{Introduction}

The period after giving birth is an important period for a mother. Because, that's when the mother breastfeeds her child. The mother gives breast milk (breast milk) exclusively from the first day of the child's birth until the next six months. In this period, children really need complete nutrition for their growth and development.

\footnotetext{
*Corresponding author at: Jl. Prof. Maas no. 3 Kampus USU, Medan - Indonesia Corresponding email: alzabil1475@gmail.com Copyright $\odot$ Published by Talenta Publisher, ISSN: 2580-6769 e-ISSN: 2580-829X Journal Homepage: https://talenta.usu.ac.id/IJNS
} 
In order for good milk to be produced, a mother must be healthy and have sufficient nutritional needs every day (Prasetyono, 2018). During breastfeeding, a mother must try to get correct information about breastfeeding. Unfortunately, many mothers do not realize the importance of breast milk for their babies, especially mothers who work outside the home (Prasetyono, 2018). The growth and development of the baby continues into adulthood. This growth and development process is influenced by the food given to the child. The most suitable food for babies is breast milk (ASI), because breast milk is intended for babies as the baby's staple food (Wiji, 2019).

The achievement of exclusive breastfeeding in Indonesia has not reached 80\%. Based on the 2013 IDHS report, the achievement of exclusive breastfeeding was $42 \%$. Meanwhile, based on a report from the Provincial Health Office in 2014, the coverage of breastfeeding 0-6 months was only 54.3\% (Pusdatin,2015. In Sihombing 2017). The Association of Indonesian Breastfeeding Mothers in North Sumatra Region (AIMI Sumut) in 2019 that the coverage of exclusive breastfeeding is still below 50\% (Astuti, 2019). From the Langkat District Health Office, 23 Public health center have implemented the exclusive breastfeeding program in Langkat Regency. Every health center that runs this program has not been able to provide maximum results increasing the coverage of exclusive breast feeding in Langkat Regency. The coverage of breastfeeding in infants reaches $90.5 \%$, but only $68.9 \%$ of babies get exclusive breastfeeding in Langkat Regency. Besitang is the highest health center with the achievement value of exclusive breastfeeding at $72.8 \%$, but the health center has not reached the target of exclusive breastfeeding in Indonesia. Public health center Bahorok, Public health center Namu Ukur, Public Health Center Tanjung Selamat are the three health centers with the lowest achievement of exclusive breastfeeding in Langkat Regency (Health Profile of Langkat Regency, 2017).

The results of the preliminary survey conducted by the researcher found that of the 15 breastfeeding mothers interviewed, 12 of them did not provide exclusive breast feeding and 3 of them gave exclusive breast feeding. Of the 12 mothers who did not provide exclusive breast feeding, 10 of them had jobs, and 2 other mothers did not have jobs (housewives). Meanwhile, out of 10 mothers who have jobs, 5 of them have good knowledge, 3 mothers have sufficient knowledge, and 2 other mothers have less knowledge

\section{Research Method}

This type of research is a descriptive analytic survey with a cross sectional approach using the Accidental Sampling technique. The research was conducted in Sidomulyo Village, Stabat District, Langkat Regency, with a population of mothers who breastfeed their babies (0-6 months) in Sidomulyo 150

people. The research sample with the following formula: $\frac{20}{100} \times 150=30$, then the number of samples in this study was 30 people. Sample criteria including inclusion criteria and exclusion criteria. Data analysis in this study uses several techniques, namely: Univariate analysis is carried out on each variable from the research results which is only used to produce the distribution and proportion of each variable 
and Bivariate analysis is carried out to see whether the two variables are suspected to be related or correlated, then this study uses chi-square. Indicators that the data can be tested using the formula $\mathrm{x}^{2}$ with the criteria of the hypothesis: If $x^{2}$ counts $>x^{2}$ table then Ho is rejected, Ha is accepted and If $x^{2}$ counts $<\mathrm{x}^{2}$ table then Ho is accepted, Ha is rejected.

\section{Result and Discussion}

The results of data collection from respondents through this study concerning the Relationship between Knowledge and Mother's Work on Exclusive Breastfeeding with 30 respondents as follows.

Table 1. Distribution of Mother's Knowledge Frequency

\begin{tabular}{ccc}
\hline Knowledge & Amount (n) & Persentage (\%) \\
\hline Good & 10 & 30.3 \\
Moderate & 14 & 42.4 \\
Poor & 6 & 18.2 \\
\hline
\end{tabular}

Based on the data above, it can be seen that the majority of mothers' knowledge is sufficient (42.4\%), and the minority of knowledge is less $(18.2 \%)$.

Table 2. Job Frequency Distribution

\begin{tabular}{ccc}
\hline Occupation & Amount (n) & Persentage (\%) \\
\hline Working Mom & 18 & 54.5 \\
Unemployed & 12 & 36.4 \\
\hline
\end{tabular}

Based on the table above, it can be seen that the majority of working mom (54.5\%) and the minority do not work (36.4\%).

Table 3. Frequency of Exclusive Breastfeeding

\begin{tabular}{ccc}
\hline Exclusive Breastfeeding & Amount (n) & Persentage (\%) \\
\hline Granted & 14 & 42.4 \\
Not Granted & 16 & 48.5 \\
\hline
\end{tabular}

Based on the table above, it can be seen that the majority of mothers who do not provide exclusive breast feeding are (48.5\%) and the minority of mothers who give exclusive breast feeding is as much $(42.4 \%)$.

Table 4. Relationship between Mother's Knowledge of Exclusive Breast feeding

\begin{tabular}{|c|c|c|c|c|c|c|c|c|}
\hline \multirow[b]{3}{*}{ Knowledge } & \multicolumn{4}{|c|}{ Exclusive Breast feeding } & \multicolumn{2}{|c|}{ Total } & \multirow[t]{3}{*}{ df } & \multirow[t]{3}{*}{ P value } \\
\hline & \multicolumn{2}{|c|}{ Granted } & \multicolumn{2}{|c|}{ Not Granted } & & & & \\
\hline & $\mathbf{n}$ & $\%$ & n & $\%$ & n & $\%$ & & \\
\hline Good & 8 & 26.7 & 2 & 6.7 & 10 & 33.3 & & \\
\hline Moderate & 5 & 16.7 & 9 & 30.0 & 14 & 46.7 & 2 & 0.026 \\
\hline Poor & 1 & 3.3 & 5 & 16.7 & 6 & 20.0 & & \\
\hline
\end{tabular}


Based on the table above, it can be seen that the majority who provide exclusive breastfeeding with good knowledge (26.7\%) and the majority do not provide exclusive breastfeeding with sufficient knowledge (30.0\%).

The results of hypothesis testing to see the relationship between variable $\mathrm{X}$ and variable $\mathrm{Y}$ are with a significant level $(a)=5 \%(0.05)$ and $d f=2$, the results obtained are p.value $=0.026$ at $\mathrm{df}=2$ where sig $<\mathrm{a}(0.026<0.05)$ then Ho is rejected and Ha is accepted, it means that there is a significant relationship between mother's knowledge of exclusive breast feeding.

Table 5. Mother's employment relationship to exclusive breast feeding

\begin{tabular}{|c|c|c|c|c|c|c|c|c|}
\hline \multirow{4}{*}{ Profession } & \multicolumn{4}{|c|}{ exclusive breast feeding } & \multicolumn{2}{|c|}{ Total } & \multirow[t]{2}{*}{ df } & \multirow[t]{2}{*}{ Pvalue } \\
\hline & \multicolumn{2}{|c|}{ Granted } & \multicolumn{2}{|c|}{ Not Grented } & & & & \\
\hline & & & & & & & & \\
\hline & $\mathbf{n}$ & $\%$ & $\mathbf{n}$ & $\%$ & $\mathbf{n}$ & $\%$ & 1 & 0.001 \\
\hline Work & 4 & 13.3 & 14 & 46.7 & 18 & 60 & & \\
\hline $\begin{array}{c}\text { Does'n } \\
\text { Work }\end{array}$ & 10 & 33.3 & 2 & 6.7 & 12 & 40 & & \\
\hline
\end{tabular}

Based on the table above, the majority of mothers who do not work exclusively breastfeed (33.3\%) and the majority do not exclusively breastfeed with working mothers (46.7\%). The results of hypothesis testing to see the relationship between variable $X$ and variable $Y$ are with a significant level $(a)=5 \%$ $(0.05)$ and dandf $=1$, the results obtained are p.value $=0.001$ padadf $=1$ where $\operatorname{sig}<a(0.001<0.05)$ then Ho is rejected and Ha accepted means that there is a significant relationship between mother's work and exclusive breast feeding.

\section{The Relationship between Mother's Knowledge of Exclusive Breastfeeding}

The results of hypothesis testing to see the relationship between variable $\mathrm{X}$ and variable $\mathrm{Y}$ are with a significant level $(a)=5 \%(0.05)$ and $d f=2$, the results obtained are p.value $=0.026$ at $d f=2$ where sig $<\mathrm{a}(0.026<0.05)$ then Ho is rejected and $\mathrm{Ha}$ is accepted, meaning that there is a significant relationship between mother's knowledge of exclusive breastfeeding in Sidomulyo Village, Kec. Stabat Kab. Leave. Exclusive breastfeeding is a form of maternal health behavior, and many factors influence it, one of which is knowledge. Mothers who have good knowledge will breastfeed exclusively because they already know the benefits, advantages and components of breast milk. In addition, mothers who do not work will have more time at home so that mothers can provide exclusive breastfeeding.

The results of this study are in line with research conducted by Titik Anggraeni (2016) which states that from the results of the chi-square test between knowledge and exclusive breastfeeding at an error rate of $5 \%(0.05)$ with $\mathrm{df}=2$, the calculated value $>2$ table $(6,587>5,591)$ then $\mathrm{H} 0$ is rejected and $\mathrm{Ha}$ is accepted, which means that there is a relationship between knowledge and exclusive breastfeeding. Knowledge has a very important role in mother's behavior because through knowledge will bring a deep understanding to the mother about the good or bad effects of giving breastfeeding exclusively. Furthermore, this understanding will be the basis for mothers to behave exclusively breastfeeding the 
babies. Good knowledge influences behavior in parenting to give breast milk only until the age of 6 months for the baby. Knowledge of exclusive breastfeeding is the basis needed so that mothers know and understand the correct actions to provide breastfeeding exclusively so that it will manifest good behavior in accordance with the knowledge they have (Furqoni N, 2018).

According to the assumptions of researchers from some informants, it shows that low knowledge results in correct breastfeeding practices but is based on a false belief, which states that breast milk is not enough for babies so that additional food must be given in the form of formula milk, honey, water, and fruits. the mushy one. This additional food is believed to help meet the baby's food and drink needs. Low knowledge of respondents also states that colostrum is not important and must be thrown away because it has been old so it becomes stale and can cause diarrhea if given to babies.

\section{Relationship between Mother's Work and Exclusive Breastfeeding}

The results of hypothesis testing to see the relationship between variable $\mathrm{X}$ and variable $\mathrm{Y}$ are at a significant level $(\mathrm{a})=5 \%(0.05)$ and $\mathrm{df}=1$, the results obtained are p.value $=0.001$ at $d f=1$ where sig $<\mathrm{a}(0.001<0.05)$ then Ho is rejected and Ha is accepted, meaning that there is a significant relationship between mother's work and exclusive breast feeding. Activities that are too dense will take time for mothers who pay attention to giving exclusive breast feeding, whereas giving exclusive breast feeding means that the mother provides the best nutrients because in breast milk that has a high nutritional value compared to formula milk.

In addition, work will affect family income so that mothers who work financially can buy formula milk with various choices (Titik Anggraeni, 2016). This is in accordance with the results of the research of Titik Anggraeni (2016) in Soekamto (2000) which states that someone who works has a higher activity than someone who does not work and someone's job can be a description of someone's social and economic abilities.For mothers who are actively working, efforts to offer exclusive breastfeeding often experience obstacles due to the fact that the short period of maternity leave and childbirth causes them to return to work before the exclusive breastfeeding period ends, this is what makes babies not exclusively breastfed, and many mothers who work assume that the breast milk is not sufficient for the baby's needs when the mother is working so that the mothers provide additional breast milk in the form of formula milk (Bahriyah, et al, 2017).

This research is in line with research conducted by Anggraeni (2016), showing that the results of the chi-square test between work and exclusive breastfeeding at an error rate of $5 \%(0.05)$ with $\mathrm{df}=1$ obtained a calculated value $>2$ table $(6.234>3.481)$ then $\mathrm{H} 0$ is rejected and $\mathrm{Ha}$ is accepted, which means that there is a relationship between work and exclusive breastfeeding. 
According to the researcher's assumption that the work status of the mother is working, it is likely that the mother does not provide exclusive breastfeeding for her baby, and the mother's employment status does not work, it is likely that the mother can provide exclusive breastfeeding. Because most mothers who work, have less time to care for their babies, so the mother not giving exclusive breastfeeding to the baby.

\section{Conclusion}

From the results of research on the relationship between knowledge and work of mothers on exclusive breastfeeding, it can be concluded that the majority of mothers' knowledge is sufficient as many as 14 respondents (42.4\%), and a minority of knowledge is less than 6 respondents (18.2\%). The majority of mothers who work are 18 respondents (54.5\%) and the minority do not work as many as 12 respondents (36.4\%). And the majority of mothers who do not provide exclusive breastfeeding are 16 respondents (48.5\%) and the minority of mothers who provide exclusive breastfeeding are 14 respondents $(42.4 \%)$. The results of hypothesis testing to see the relationship between variable $\mathrm{X}$ and variable $\mathrm{Y}$ are with a significant level $(a)=5 \%(0.05)$ and $d f=2$, the results obtained are p.value $=0.026$ at $\mathrm{df}=2$ where sig $<\mathrm{a}(0.026<0.05)$ then Ho is rejected and $\mathrm{Ha}$ is accepted, meaning that there is a significant relationship between mother's knowledge of exclusive breast feeding. The results of hypothesis testing to see the relationship between variable $X$ and variable $Y$ are with a significant level $(a)=5 \%(0.05)$ and $\mathrm{df}=1$, the result is $p$ value $=0.001$ at $d f=1$ where sig < a $(0.001<0.05)$ then Ho is rejected and Ha is accepted, meaning that there is a significant relationship between mother's work and exclusive breast feeding

\section{Acknowledgement}

The author would like to thank all parties for their support and cooperation during the research

\section{Conflict of Interest}

There is no conflict of interest in this study.

\section{REFERENCES}

[1] Arikunto, S. 2016. Prosedur Penelitian :Suatu Pendekatan Praktik. Jakarta: Rineka Cipta

[2] Anggraeni, T. 2016. Hubungan Pengetahuan Dan Pekerjaan Ibu Dengan Pemberian ASI Eksklusif Di Posyandu Lestari Handayani Desa Jembungan Kabupaten Boyolali. Jurnal Ilmiah Rekam Medis dan Informatika Kesehatan. 6(1):47-54

[3] Bahriyah, F, dkk. 2017. Hubungan Pekerjaan Ibu Terhadap Pemberian ASI Eksklusif Pada Bayi. Journal Endurance. 2(2):113-118

[4] Fahmi, YB. 2019. Hubungan Pengetahuan Ibu Dan Pekerjaan Ibu Dengan KeberhasilanPemberian ASI Eksklusif Di Puskesmas RambahSamo I. Jurnal Maternity and Neonatal. 2(6):350-357 
[5] Haryati, dkk. 2016. Hubungan Pengetahuan Dan Status Pekerjaan Ibu Dengan Pemberian ASI Eksklusif Pada Bayi 0-6 Bulan Di Kelurahan Tambun Kecamatan Baolan Kabupaten Tolitoli. Promotif. 6(2):129-136

[6] Jauhari, I. 2018. Perlindungan Hak Anak Terhadap Pemberian Air SusuIbu (ASI). Yogyakarta: Deepublish

[7] Khamzah, SN. 2018. Segudang Keajaiban ASI yang Harus Anda Ketahui. Jogjakarta: Flash Books

[8] Kementerian Kesehatan RI. 2015. Dukung Ibu Bekerja Beri ASI Eksklusif. www.depkes.go.id diakses pada tanggal 18 Januari 2019

[9] Notoatmodjo, S. 2018. Metodologi Penelitian Kesehatan. Jakarta: Rineka Cipta

[10] Prasetyono, DS. 2018. Buku Pintar ASI Eksklusif. Jogjakarta: Diva Press

[11] Panjaitan, N.2014. Relationship between characteristics Of mother and eating patterns to the Growth and Development of insfants at pangkalan susu district langkat regency.Jurnal Kesehatan Surya Nusantara.Vol 3.

[12] Pusdatin. 2015. Pusat Data dan Informasi Kementerian Kesehatan. www.pusdatin.kemkes.go.id/article/view/diaksespa datanggal 18 Januari 2019

[13] Sihombing, S. 2018. Hubungan Pekerjaan Dan Pendidikan Ibu Dengan Pemberian ASI Eksklusif Di Wilayah Kerja Puskesmas Hinai Kiri. Jurnal Bidan. 5(01):40-45

[14] Simanungkalit, HM. 2018. Status Pekerjaan Dan Pengetahuan Ibu Menyusui Terhadap Pemberian ASI Eksklusif. Jurnal Info Kesehatan. 16(2):236-244

[15] Timporok, AG. 2018. Hubungan Status Pekerjaan Ibu Dengan Pemberian ASI Eksklusif Di Wilayah Kerja Kawangkoan. e-Journal Keperawatan. 6(1):01-06

[16] Wiji, RN. 2019. ASI dan Panduan IbuMenyusui. Yogyakarta: NuhaMedika

[17] Yosephin, B, dkk. 2019. Buku Pegangan KUA: Sebagai Konselor 1000 HPK Dalam Mengedukasi Calon Pengantin Menuju Bengkulu Bebas Stunting. Yogyakarta: Deepublish 